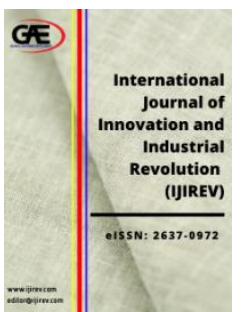

\author{
INTERNATIONAL JOURNAL OF \\ INNOVATION AND \\ INDUSTRIAL REVOLUTION \\ (IJIREV) \\ www.ijirev.com
}

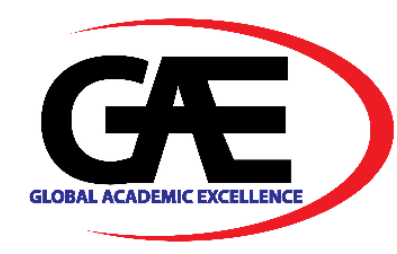

\title{
SAGO STARCH COMPRESSING MACHINE: INCREASING THE PRODUCTIVITY WITH NEW CONCEPT
}

\author{
1 Department of Mechanical Engineering, Politeknik Mukah, Malaysia \\ Email: farihana@pmu.edu.my \\ 2 Department of Mechanical Engineering, Politeknik Mukah, Malaysia \\ Email: fadila.shaari@pmu.edu.my \\ 3 Department of Mechanical Engineering, Politeknik Mukah, Malaysia \\ Email: brenda@pmu.edu.my \\ Corresponding Author
}

Farihana A.Rahman ${ }^{1 *}$, Syarfadila Ezurida Shaari ${ }^{2}$, Brenda Anak Norbert Rabar ${ }^{3}$

\section{Article Info: \\ Article history: \\ Received date: 15.02 .2021 \\ Revised date: 18.03.2021 \\ Accepted date: 23.05 .2021 \\ Published date: 15.06 .2021 \\ To cite this document: \\ Rahman, F. A., Shaari, S. E., \& Rabar, B. A. N. (2021). Sago Starch Compressing Machine: Increasing The Productivity With New Concept. International Journal of Innovation and Industrial Revolution, 3 (7), 10- 18.}

DOI: $10.35631 /$ IJIREV.37002

This work is licensed under $\underline{\mathrm{CC} B Y} 4.0$ (c) (2)

\begin{abstract}
:
Sago is the staple food of Melanau in Sarawak. Sago is sourced from Pokok Rumbia or known as Pokok Sagu which is widely found in the interior of the forest. Pokok Rumbia is a kind of palm tree found in Malaysia and Indonesia forests. Among the products of sago trees is wet sago starch or 'Lemantak'. Wet sago starch is still traditionally produced by Small and Medium Enterprises (SMEs). By utilizing the compressed air produced using the singleacting cylinder from a pneumatic system, the sago starch is compressed with 1.5 horsepower. Through careful selections of concepts, the final selected concept was fabricated and analysed. Machine efficiency analysis is determined by taking into account the compressor pressure factor, the time taken for compression, the height of wet sago starch, and the rate of production at a given time. It is proven that with the implementation of the process through the new machine concept, the productivity of 'Lemantak' has increased by $68 \%$ compared to the conventional method of production.
\end{abstract}

Keywords:

Mechanical, Design, Sago Starch, Pneumatic, Compressing Machine

\section{Introduction}

In the 19th century, the sago palm exploitation started in Sarawak from Oya to Mukah along with Igan, Balingian and Dalat districts. The Melanau lived off by the sago palm tree. The Sago palm starch is unique compared to other starch-based crops. The palm grows well in swampy Copyright $\odot$ GLOBAL ACADEMIC EXCELLENCE (M) SDN BHD - All rights reserved 


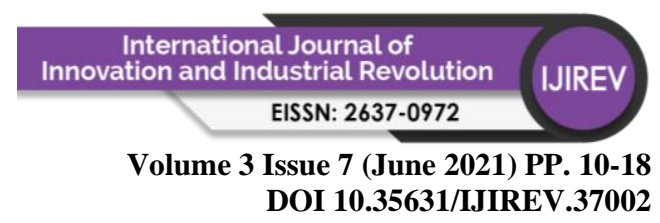

areas, which can only developed for other crops at a high cost. It is perineal, very suitable for humid tropical lowlands and is already available in areas that are in urgent need of economic in this region. Sago palms grow very quickly; one sucker matures, then flowers and dies. Another sucker has replaced it. The stems are thick and self-supporting or have a moderate climbing habit and the leaves are pinnate. One palm produces a single flower at the tip of the palm. (E. J. DaSilva, 1992)

Unlike other palms three, sago reproduces only once before dying. Sago palms harvested just before flowering when the stems are full of starch stored for use in reproduction. One palm can yield $150-300 \mathrm{~kg}$ of starch. Wet sago starch is widely used in Mukah and the process of making it is hard because it required a lot of manpower. Thus, this machine designed to ease the process of compressing and packing wet sago starch. A wet sago starch, if exposed to air it will turn sour quickly, thus the researcher decided to design a better way to pack the wet sago starch with high efficiency and speed. This paper aims to select the best concept machine to compress a wet sago starch and to help increase the productivity of sago starch. This concept implements a pneumatic system as the main mechanism for compressing the sago starch to become a 'lemantak'.

\section{Literature Review}

There are two points that will be discuss in the literature review, sago palm processing and pneumatic machine.

\section{Sago Palm Processing}

The importance of starch by sago palm mainly focused in the Asia-Pacific region and South East Asia (AA Karim, 2008). Useful quantities of starch-rich flour can be extract from stem tissue by shredding and sedimentation in water from a species. The palm is by far the most important economic species and is grows commercially in Malaysia, Indonesia, the Philippines and New Guinea for the production of sago starch and conversion to animal food or fuel ethanol. Sago is the highest starch producer among all starch crops of the world, rice, corn, wheat and potato. Sago also is an extremely hardy plant, thriving in swampy, acidic peat soils, submerged and saline soils where few other crops survive, growing more slowly in peat soil than in mineral soil.

Sago and tapioca starch are two of the main locally sourced starch marketed in Malaysia. Traditionally processed sago starch, commonly known as 'lemantak', are extracted manually from the trunk of sago palm (Metroxylon sagu), and followed by processes of washing, sedimentation and drying (Arshad, N. H. et al, 2018). The process of a sago palm tree's first step is to identify the types of trees to cut down. The sago palm tree then divided into eight sections. There is three important part of a sago palm tree, the first part before logging the trees, the first part is necessary to be clean using machetes. The second part was the harvested part and before it divided into eight sections, and the last part needs to be soaked in the water for 20 days. After the process of chopping the sago palms trees, the part rolled leading to the banks of the river. Next, the parts placed directly into the river before tied together using a rope. The parts are consolidated with the rafts then it pulled using boats or manpower. The parts of the boat can be withdrawn if the river water is bunged up, if the river water receded, then manpower is will be needed to pull the sago tree's parts. Once finished the process of chopping down the sago palm trees, small parts of the soaked sago palm tree for 20 days in the river to ensure the Sago is processed has sufficient content, other than that the soaking process is to avoid getting 


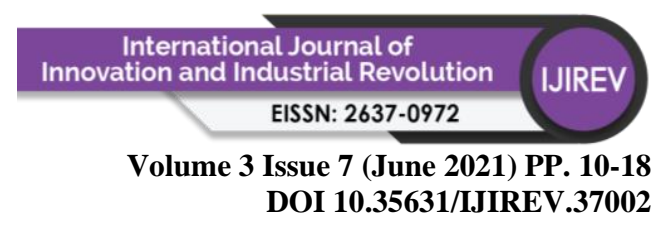

eaten by worms. The wet soaked sago stump then goes through the shredding process, the stumped then shredded using a wooden board equipped with nail known as 'garus'. More water added into the shredded pieces of sago, which consist of fibre and piths before kneaded, filtered and wrung, isolating the liquid from the starch. This wet or moist starch is compressed, dried and packed thus producing what known as 'Lemantak' (Abd Aziz, 2002).

\section{Pneumatic Machine}

The pneumatic press tool has the advantage of working in low pressure, that is even pressure of 6 bar is enough for operating the unit. The pressurized air passing through the tubes to the cylinder forces the piston out whose power through the linkage transmitted to the punch. The workpiece thus got is for required dimensions and the piece can be collect through the land clearance provided in the die. The die used in this fixed such that the die of the required shape can be used according to the requirement.

The key part of any facility for the supply of compressed air is the compressor. A compressor is a machine that takes in air, gas or vapours at any certain pressure and delivers the air at high pressure. Compressor capacity is the actual quantity of air compressed and delivered and the volume expressed is that of the air at intake conditions, namely at atmospheric pressure and normal ambient temperature. Clean condition of the suction air is one of the factors, which decides the life of the compressors.

According to this research, the manual compressor shown in Figure 1 is made of steel, its build to compress a wet sago starch. This manual tool currently used in the market. It uses manpower to operate. This tool can compress wet sago starches for 50 pieces in 30 minute and it takes one time to press to get the exact height of a 'lemantak'.

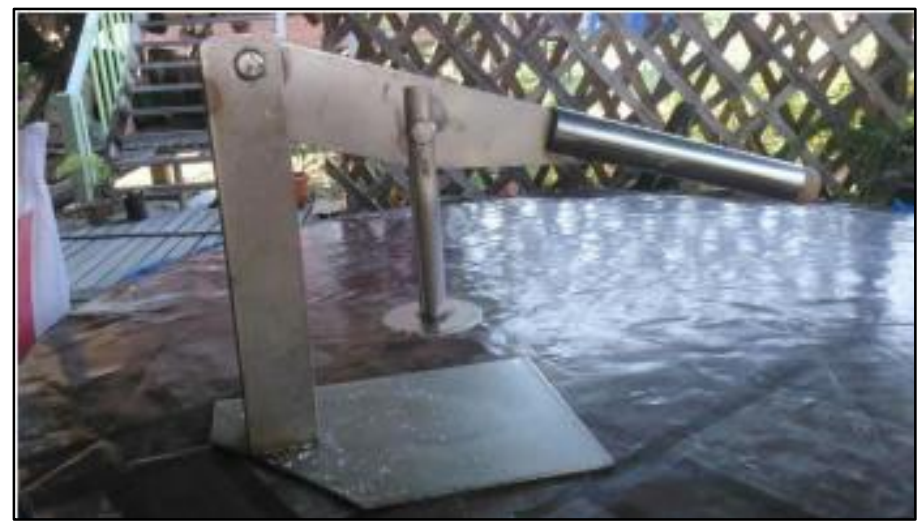

Figure 1: A Traditional Wet Sago Starch Compressor

\section{Methodology}

A normal sago starch press is a manual machine that uses manpower to handle it. This design created is also manual but use less manpower. The contraction of the compression can be hydraulic, pneumatic or mechanical. In this case, a pneumatic system chosen. Pneumatic is more clean than hydraulic and mechanical because pneumatic does not use oil. Furthermore, pneumatic is easier to handle.

Figure 2 below shows the process of designing the Sago Starch Compressing Machine. The problems were identify according to the needs of the small-scale industry. Based on the problem identified, the product specifications and design concept were determined. Then, Copyright $\odot$ GLOBAL ACADEMIC EXCELLENCE (M) SDN BHD - All rights reserved 
Volume 3 Issue 7 (June 2021) PP. 10-18 DOI 10.35631/IJIREV.37002

concept development and evaluation carried out. If the process is going smoothly, then proceed to detailed design and material selection. Last, the design of the sago starch-compressing machine carried out to the final. However, if the concept development and evaluation cannot proceed, then need to go back to determine the design concept.

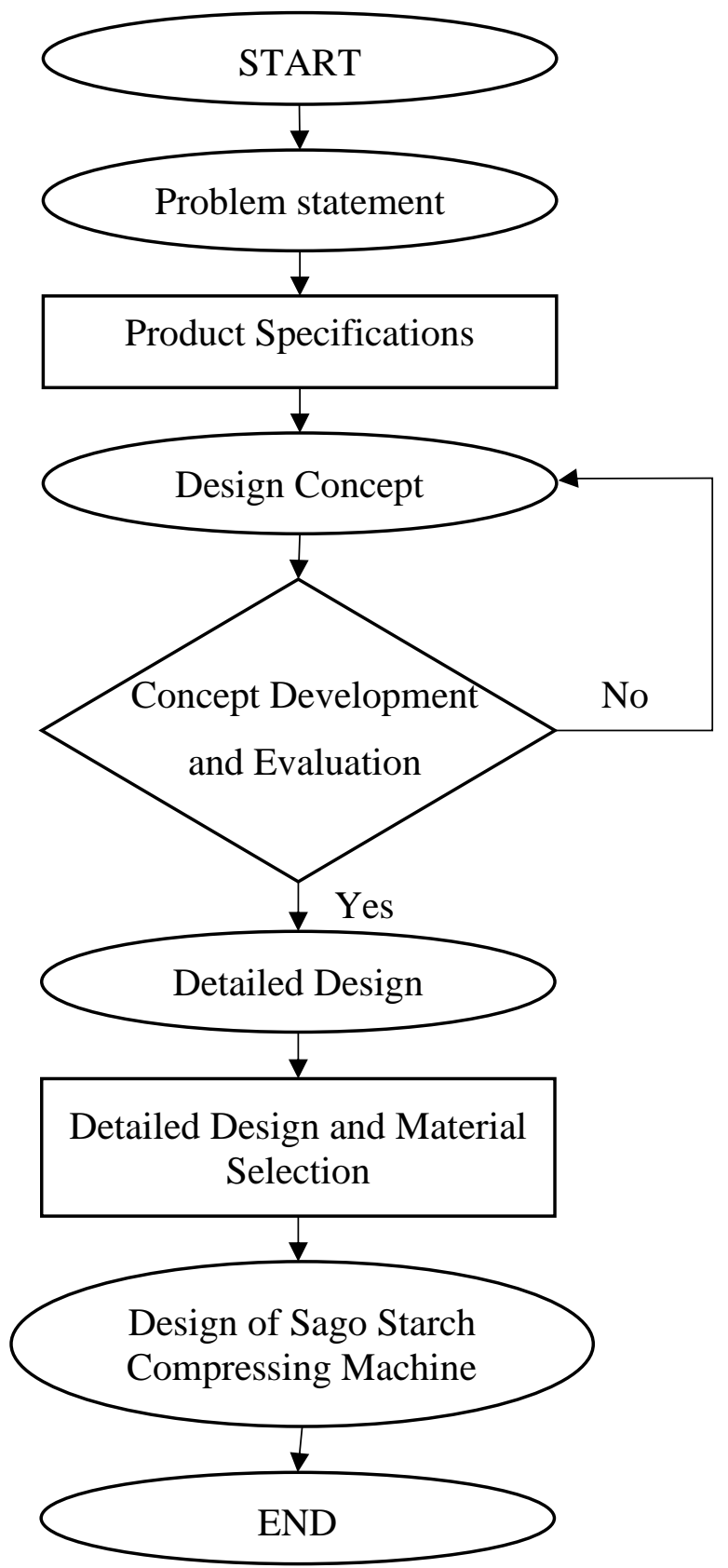

Figure 2: Product Design Flow Chart 


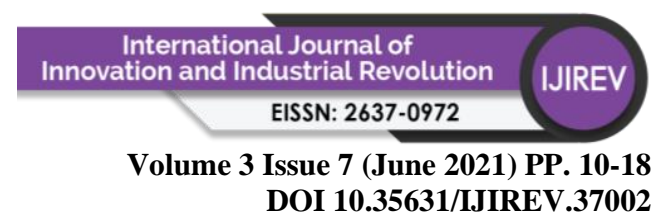

\section{Product Design Specification}

Product Design Specification is to understand the required specification to design the machine. Table 1 shows some of the major criteria considered for product design specification. The machine is using a pneumatic system and the compressing process is using a double-acting cylinder, which requires two air supplies, one to outstroke the piston and the other to instroke the piston. The material used for the machine is aluminium and stainless steel because it is lightweight and more durable. The compressor is to convert the mechanical energy from motors and engines into the potential energy to compress the sago starch to become 'lemantak'. The machine is target at small-scale industry entrepreneur as so many of them are still using the traditional ways to produce 'lemantak'. The estimation of the total cost is approximately RM850.00.

Table 1: Product Design Specification

\begin{tabular}{|l|l|l|}
\hline No. & Description & Specification \\
\hline 1 & Name & Sago Starch Compressing Machine \\
\hline 2 & Mechanism & Pneumatic \\
\hline 3 & Target Customer & Small scale industry entrepreneur \\
\hline 4 & $\begin{array}{l}\text { Compressing } \\
\text { process }\end{array}$ & Double-acting cylinder \\
\hline 5 & Material & $\begin{array}{l}\text { Aluminium and stainless steel for the structural frame, } \\
\text { compressor }\end{array}$ \\
\hline 6 & Safety & Structural frame to guard the pneumatic system \\
\hline 7 & Compressor & $\begin{array}{l}\text { Convert the mechanical energy from motors and engines into } \\
\text { the potential energy in compressed air }\end{array}$ \\
\hline 8 & $\begin{array}{l}\text { Double-acting } \\
\text { cylinder }\end{array}$ & $\begin{array}{l}\text { Requires two air supplies, one to outstroke the piston and the } \\
\text { other to instroke the piston }\end{array}$ \\
\hline 9 & Cost & Approximately RM850.00 \\
\hline
\end{tabular}

\section{Concept Design}

There are several designs to be chose in concept design. However, based on the criteria taken into account, a pneumatic system is more suitable to fabricate the machine. Table 2 shows the design concept. First, the pneumatic cylinder or piston chosen for the compression method because of the effectiveness and it is widely used in the food industry. The pneumatic air compression to the cylinder can be control easily. Compressing method using pneumatic is more hygiene than hydraulic due to oily process. Meanwhile, pneumatic used air as energy.

Second, the efficiency of compressing for a pneumatic system is more efficient compared to manual and electric motor due to the fast compression. It is also easier to set up the circuit compared to other methods because it is using air to press and move the piston. Pneumatic system is also hygiene and safe to use in food packaging. Various manufacture and industry use the system widely because of its safeness. Lastly, double-acting cylinders used more oftenin pneumatic systems than single-acting cylinders. They are able to produce greater forces and we can take advantage of both the outstroke and instroke forces to lift and move objects. 
Volume 3 Issue 7 (June 2021) PP. 10-18 DOI 10.35631/IJIREV.37002

Table 2: Design Concept

\begin{tabular}{|l|c|c|c|c|}
\hline $\begin{array}{l}\text { Compression } \\
\text { method }\end{array}$ & Option 1 & Option 2 & Option 3 \\
\hline Cylinder & & & \\
\hline
\end{tabular}

The Design of Sago Starch Compressing Machine

Based on the design concept and evaluation, the final design shown in the figures below. Figure 3, Figure 4 and Figure 5 show the front view, the side view and the top view of the detailed design respectively. Whereas, Figure 6 shows the final design of the Sago Starch Compressing Machine.

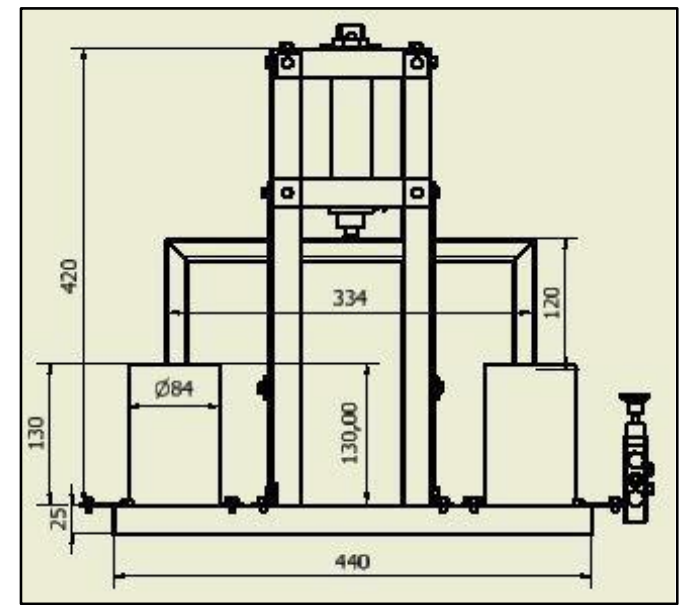

Figure 3: Front View of The Detailed Design 
Volume 3 Issue 7 (June 2021) PP. 10-18 DOI 10.35631/IJIREV.37002

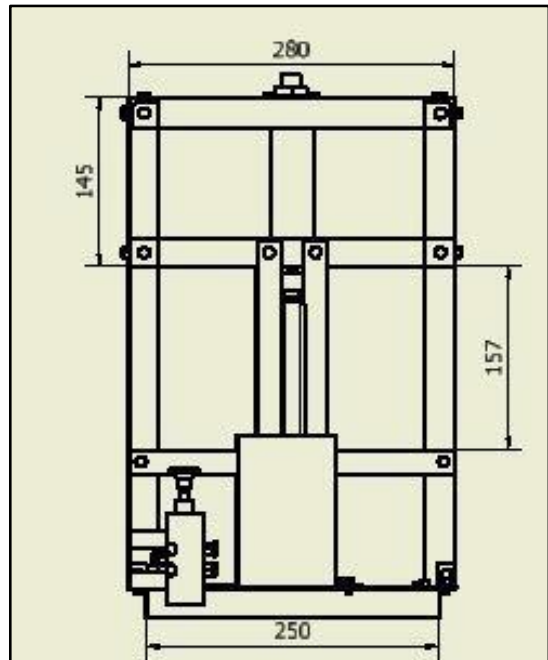

Figure 4: Side View of The Detailed Design

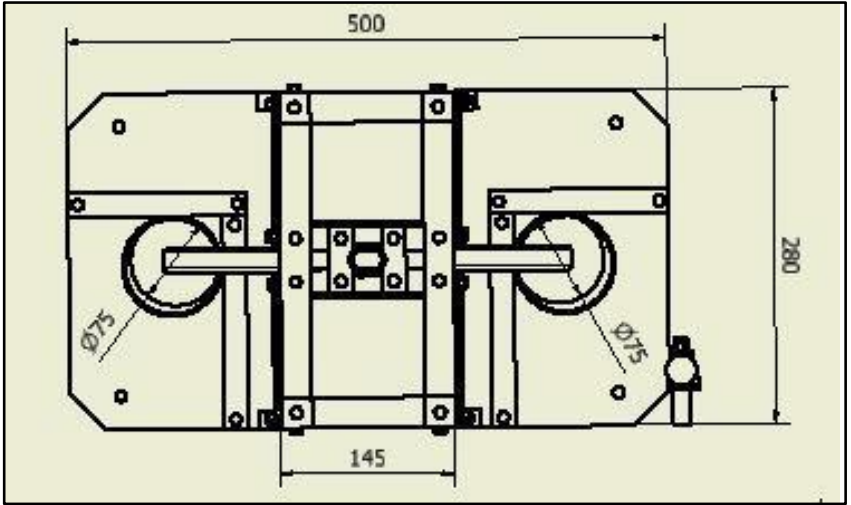

Figure 5: Top View Of The Detailed Design
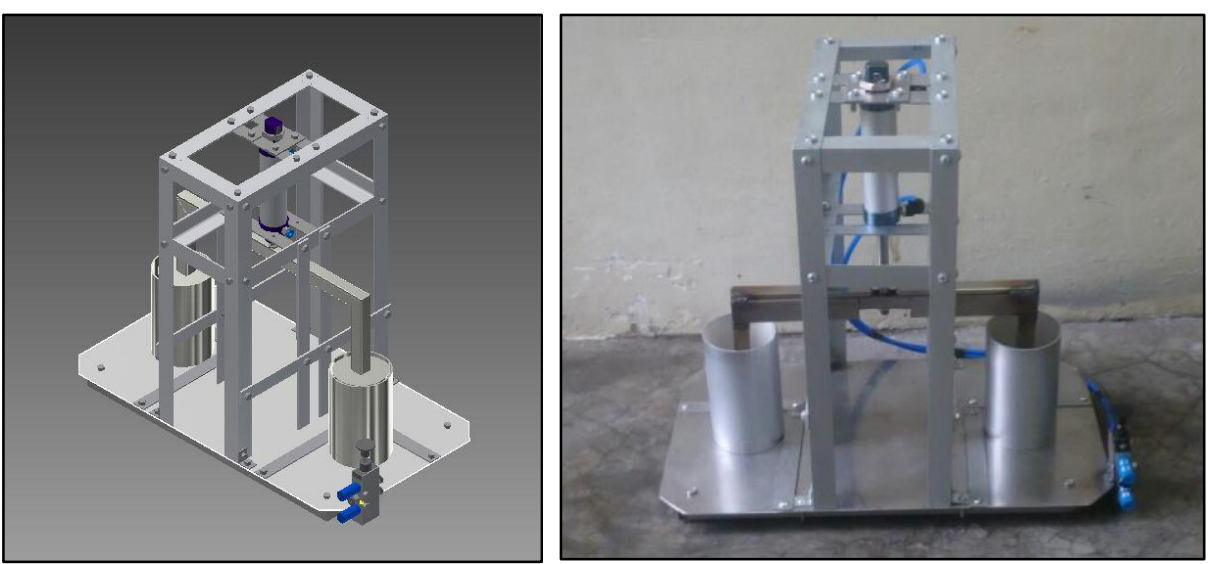

Figure 6: Final Design Of Sago Starch Compressing Machine

\section{Discussion}

'Lemantak' height is directly proportional with pressure. The wrong mixing of dough will result in the final product either squishy or hard. Otherwise, it will affect the final product in terms of its height. 'Lemantak' must be produce with the perfect mix of dough and with suitable pressure to get the perfect one. Based on the data analysis that has been obtained, the perfect 


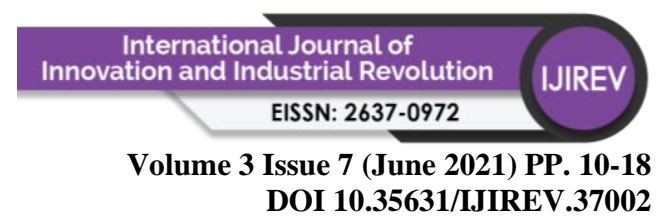

ratio of water and sago starch is 0.5 litre: $1 \mathrm{~kg}$ to have the perfect mixture of dough. The suitable pressure of the compressor is 6 bar with the result of 'lemantak' height is $8.0 \mathrm{~cm}$ to $8.2 \mathrm{~cm}$. The production time of 'lemantak' using the machine is $0.36 \mathrm{~min} / \mathrm{unit}$. Based on the production result, the production increasing $40 \%$ compared to the traditional method.

\section{Conclusion}

Based on the results obtained, it can be concluded that with the usage of a sago starch compressing machine, the production of a wet sago starch or 'lemantak' can be increased. The use of a compressor helps to speed up and facilitate the production of 'lemantak' more effectively. Suitable design of compressing machine can be practice in the manufacture of 'lemantak'. This is great for the SME entrepreneur, as the productivity is higher and at the same time, it can lessen the manpower to produce 'lemantak' by using compressor instead of human energy. Therefore, the machine has provided opportunities and solved the problems faced by the SME entrepreneur where it fulfils the needs of the SME entrepreneur.

\section{References}

Arshad, N. H., Zaman, S. A., Rawi, M. H., Sarbini, S. R. (2018). Resistant starch evaluation and in vitro fermentation of lemantak (native sago starch), for prebiotic assessment. International Food Research Journal 25(3), 951-957.

Aziz, S. A. (2002). Sago Starch and Its Utilisation. Journal of Bioscience and Bioengineering 94(6), 526-529.

Cross, N. (2008). Engineering Design Methods: Strategies for Product Design, 4th Edition. Chichester: Wiley.

Ehara, H., Toyoda, Y., \& Johnson D. V. (2015). Sago Palm Multiple Contributions to Food Security and Sustainable Livelihoods.

E. J. DaSilva, C. Ratledge, A. Sasson. (1992). Biotechnology: Economic and Social Aspects Issues for Developing Countries. Cambridge: Cambridge University Press. doi:10.1017/CBO9780511760075

Karim, A. A., Tie, A., Manan, D. M. A., \& Zaidul, I. S. M. (2008). Starch from the sago (Metroxylon sagu) palm tree-properties, prospects, and challenges as a new industrial source for food and other uses. Comprehensive Reviews in Food Science and Food Safety, 7(3), 215-228. Blackwell Publishing Inc.

Karl T. Ulrich, S. D. (2008). Product Design and Development 4th Edition. New York: McGraw Hill.

Metaragakusuma, A. P., Katsuya, O., \& Bai, H. (2016). An Overview of The Traditional Use of Sago for Sago-based Food Industry in Indonesia. ICoA Conference Proceedings, (3), 119-124.

Mustafa Kamal, M., Baini, R., Lim, S. F., Rahman, M. R., Mohamaddan, S., \& Hussain, H. (2019). Drying effect on the properties of traditionally processed sago starch. International Food Research Journal, 26(6), 1861-1869.

Mustafa Kamal, M., Baini, R., Mohamaddan, S., Selaman, O. S., Ahmad Zauzi, N., Rahman, N. R., Abdul Rahman, N., Chong, K. H., Atan M. F., Abdul Samat N. A. S., Taib S. N. L., \& Othman, A. K. (2017). Effect of temperature to the properties of sago starch. IOP Conf. Series: Materials Science and Engineering, (206), doi:10.1088/1757$899 X / 206 / 1 / 012039$

Polapragada, A. A., \& Varsha, K. S. (2012). Pneumatic Auto Feed Punching and Riveting Machine. In International Journal of Engineering Research and Technology, 1(7), ESRSA Publications. 
Volume 3 Issue 7 (June 2021) PP. 10-18 DOI 10.35631/IJIREV.37002

Singhal, R. S., Kennedy, J. F., Gopalakrishnan, S. M., Kaczmarek, A., Knill, C. J., \& Akmar P. F. (2008). Industrial production, processing, and utilization of sago palm-derived products. Carbohydrate Polymers. (72), 1-20.

Sageng, C.W., Kasa, M., Pudun, J.M. \& Ramli, N. (2020). Sarawak Cuisine: An Overview and Its Identity. Journal of Tourism, Hospitality \& Culinary Arts, 12(3), 15-30.

Tamizharasi, G., Kathiresan, S., Balaji, D., \& Jegathiesan, S. (2015). Low-Cost Automation in a Power Press. Indian Journal of Science and Technology, 8(32).

Vaghela, R., Patel, R., \& Kanaksinh, G. (2016). A Review on Design \& Analysis of C-Frame of Pneumatic Power Press Using FEA.

Widodo, R. T., \& Hassan, A. (2015). Compression and mechanical properties of directly compressible pregelatinized sago starches. Powder Technology, (269), 15-21.

Yuan, J., Hiltner, A., \& Baer, E. (1983). The mechanical properties of PVC under high pressure. Journal of materials science, 18(10), 3063-3071.

Zhu, F. (2019). Recent advances in modifications and applications of sago starch. Food Hydrocolloids, (96), 412-423. 